\title{
HISTORY OF DEVELOPMENT OF SCHOOLS OF FINE ARTS AND COMPOSITION IN THE TERRITORY OF ANCIENT UZBEKISTAN
}

\author{
Botir Boltabayevich Baimetov \\ Professor, Chirchik State Pedagogical Institute, Tashkent Region, Uzbekistan, \\ Farhod Sattorov
}

1 Course Of Master's Degree, Namangan State University

\begin{abstract}
The article provides historical information on the history of the development of schools of fine arts and
composition in the territory of ancient Uzbekistan. It also discusses the development of fine arts and
composition in the manuscripts of miniature art, the artists' attempts to reflect the historical events of the
miniature, to accurately depict the human face.
KEYWORDS:- Art of the ancient East and Uzbekistan, composition, fine arts.

\section{INTRODUCTION}

The first images in human history were drawn on a graphic path, on rocks, on cave rocks. Images found in Zarautsoy cave are an example of this. From the ancient images we can see the images of wild bulls, deer, mountain goats, pigs, wolves, tigers and other wild animals, hunting on the rocks of "Sarmishsay" in the foothills of Zarafshan. In these images, people tried to express every thought, every feeling.

Ancient people believed in different religions and created statues to satisfy their beliefs. Samples of compositions made of clay, stone, wood, bone have come down to us. These images of the past

are reliable and important examples of the fine arts of Uzbekistan.

Afrosiab, one of the cultural centers of the Eastern past, is a place that reflects the art of the VII century BC. It is known from history that Alexander's army conquered Central Asia in 329337 BC, and Alexander promoted the Greek language, culture, and religion in the occupied territories from Greece to Central Asia. As a result, a harmonization began between the fine and applied arts of the indigenous peoples and the art of the Hellenes. This harmony lasted a long time and began to appear in Hellenistic sculpture, murals, and examples of applied art, including architecture. During excavations in the ruins of Afrosiab was found a precious stone
\end{abstract}


CURRENT RESEARCH JOURNAL OF PHILOLOGICAL SCIENCES 2(5): 05-12,

May 2021 DOI: https://doi.org/10.37547/philological-crjps-02-05-03

ISSN 2767-3758

(C)2021 Master Journals

\section{Crossref do) 81 Google}

Accepted21 $1^{\text {th }}$ May, 2021 \& Published 26 $6^{\text {th }}$ May, 2021

with a picture of Alexander. The stone is the size of a nail and is believed to be the eye of a gold ring lost by Alexander's troops during the conquest of Samarkand.

\section{Material AND METHods}

The kingdom of Kushan is actually a political concept, and its geographical name is Bactria. The statues found in the area promote ideas such as love, family happiness, and fertility. Archaeological excavations have uncovered statues of the Buddha standing upright. During this period, the creation of Buddhist temples, in turn, led to the development of artistic ornaments typical of Buddhism. In sculptures such as the "Buddha" at the top of the old woman and the "Devatto head" at Dalverzintepa, the shapes and positions on the face, eyes, nose, and lips correspond to proportional balances. Examples include the crowned Prince of Kushan and dozens of other statues found at Darverzintepa.

In the middle of the last century, a world-class event took place in the study of our cultural heritage in the Central Asian region. As a result of archeological excavations in the ancient site of Samarkand (belonging to the VII century BC) under the name of Afrosiyob were found exquisite murals. The existence of such a colorful color art indicates that the art is highly developed. The most characteristic example of Afrosiyob color art is the appearance of the royal palace. According to Archaeologists has identified V.A. Shishkin, Ya.G. Gulyamov, L.I. Albaum, the most majestic wall color composition is located in the central royal palace.

The palace is square in shape $11 \times 11$ meters, wall height $2 \mathrm{~m}$. The paintings on these walls are kept in a different condition. The images on the south side of the wall are better preserved. The picture shows a ceremonial march from the spectator to the left towards the castle. From the beginning to the end of the south wall we see the image of elephants, camels, riders on horses dressed in beautiful costumes. The White Elephant is sitting on the Princess leading the caravan. The maid on horseback, who accompanies the procession, depicts three close women of the princess, followed by two camels, one with a thin mustache, a young man with a black beard, and the other with a white-haired mustache, a large blue-eyed brunette old man.

They are depicted with a whip in their hands representing the spirit of the palace and a long sword at the waist, a short dagger dress, and then two men with their mouths tied, watching the white birds. They are followed by a giant rider on a yellow horse, with a picture of a white bird, a prince sitting in a decorated red cloak, a belt with a gold belt, a sword and a bow and arrow. The images in the specially designed bag on the elephant are involuntarily captivating. We also see an image of a winged lion on a blanket decorated on an elephant. The image of a woman with a graceful beauty typical of the peoples of the East, the chair and the forms in her dress are elegantly expressed.

On the western part of the wall there is a depiction of three heroes (men) in expensive ornate costumes, and the image of legendary birds with beautiful jewelry around their necks. The eastern part of the wall is depicted with fruit branches in the hands of two men on a background of a blue wall. Here, according to archaeologists, the rest period after the hunt is represented. Image, color greases are not well preserved. But a fish swimming in a wave of water can identify the image of a turtle duck, a young child. The artist used borderline colors: black, white, blue, yellow, red and brown. Yet with great skill in colors, it is natural that it can attract any master of art as well. From the rich 
CURRENT RESEARCH JOURNAL OF PHILOLOGICAL SCIENCES 2(5): 05-12,

May 2021 DOI: https://doi.org/10.37547/philological-crjps-02-05-03

ISSN 2767-3758

(C)2021 Master Journals

\section{Crossref do) 81 Google}

Accepted21 ${ }^{\text {th }}$ May, 2021 \& Published 26 ${ }^{\text {th }}$ May, 2021

depiction of the composition, we see that Afrosiab's fine art has finally achieved a high level of artistic achievement. This is a testament to the skill of an experienced artist who knows the secrets of imagery well.

The four sides of the walls of the luxurious palace found at the Bolaliktepa monument near Termez are also filled with colorful images of various appearances. In the art of childhood painting, people's moods, relationships, characters are masterfully depicted by the artist. The image of the glasses in the hands of the people, the sincere compliments to each other, the servants holding a handkerchief in the background, the feast in the state of the wedding are expressed. The childhood image of the Balaliktepa Tower is significant in that the human image is often expressed. The subtle depiction of the innerforgiveness of the human image in the paintings indicates the level of serfdom of the artists of that period.

Remains of a luxurious palace with murals were also found in Varakhsha, one of the ancient cultural centers of Bukhara. The walls of the palace are decorated with photo ornaments, colorful patterns. However, it is also possible to observe aspects that differ from the medium. One of the murals depicts a middle-aged man riding an elephant, one leg on a stretcher and one leg bent. The picture also shows a majestic animal resembling a lion attacking an elephant. Varakhsha's other murals also feature luxurious views dedicated to the king's reception. In general, the images are enriched with colorful scenery and have a special meaning. In the IX-XI centuries the Samanid, Ghaznavid and Seljuk empires were formed, and their central cities such as Bukhara, Ghazna, Merv, Nishapur became centers of culture and art. During this period, artists decorated the books of such scholars as Beruni, Ibn Sina, Khayyam, Mahmud al-Kashgari, Rudaki, Firdavsi, Nizami with artistic ornaments and miniatures.
By the fourteenth and fifteenth centuries, the art of miniature had developed in Central Asia as a result of the re-copying of manuscripts. The artist tried to accurately depict miniature historical events, to accurately depict the human face. This is how the portraits of Alexander the Great and Sultan Sanjar are depicted in miniature works. The 14th-century miniature portraits of Rashid al-Din, now preserved in the National Library in Paris, are the oldest works of fine art in Central Asia.

By the 16th century, Samarkand was depicted on the walls of Amir Temur's "Boghi-Shamol" and "Boghi-Dilkusho" palaces, in western marches, battles and hunting ceremonies with his concubines, Amir and princes by the miniature artist of his time Ahmad-Boghi-Shamol.

In the time of Ulugbek, fine arts developed again. An astronomical miniature created by Abdurahman as-Sufi in 1437 contains the image of stars. In the color images, the general background is reflected by the names of the structure and location of the stars. Historians write that the walls of the rooms of the Abrurazzaq Samarkand Mirzo Ulugbek Observatory depict the view of nine skies, levels of domes, minutes and seconds, seven wild planets, stars, climates, mountains, sea, desert and related objects and animals.

The flourishing development of Central Asian miniature art began in the 15 th century. In the second half of the 15th century, Herat became a hotbed of culture under the leadership of the great Uzbek poet Alisher Navoi in the reign of Hussein Baykaro. Among the representatives of literature and art in Herat, K. Behzod shines as a free star. The great miniature artist has left us a legacy of his contemporaries: Sultan Hussein Baykaro, Shaibanikhan, poets Jami, Hatefi, etc. The portraits are characterized by deep moods. In his memoirs, Babur describes the appearance of the portrait of Sultan Hussein Baykaro as 
CURRENT RESEARCH JOURNAL OF PHILOLOGICAL SCIENCES 2(5): 05-12,

May 2021 DOI: https://doi.org/10.37547/philological-crjps-02-05-03

ISSN 2767-3758

(C)2021 Master Journals

\section{Crossref do) 81 Google}

Accepted21 ${ }^{\text {th }}$ May, 2021 \& Published 26 ${ }^{\text {th }}$ May, 2021

follows: he was a majestic, majestic, handsome lion, slender below the waist. He created a portrait of the Uzbek khan Shaybanikhan Bekhzod, who had been a state refuge in the prosperous Khorasan for 40 years, after the capture of Herat in 1507. He was a great general, a statesman, a scholar, a man who highly valued literature and art. The khan was sitting in a short, light, simple robe with a turban on his head. The heavy, straight-eyed hand is depicted on the knee in the image of a large-hearted man with a strong face.

Behzod's portraits are depicted in solid colors. The clear and plastic construction features of the lines represent the image of Shaybanikhan's powerful shoulder girdle.

In the portrait of Shaybanikhan, objects such as an inkwell book in the interior, a ring on the big right finger of the whip, enrich the viewer, revealing the image of the great commander. Kamoliddin Behzod reached the peak of portrait miniature art in his works at that time. Other artists also created miniature art at the residence of Hussein Baykaro. In 1498, the historian Khandamir, in his pamphlet "Khulasat Al-Akbar", described the artist Qasim-Ali as the cream of the century, the leader of the authors of delicate works. He had mastered the secrets of art at the Hussein Baykaro Library under his guidance. At the Shaybanikhan Palace, one of Behzod's gifted students, Mahmud Muzahhib (Muzahhib means annoyed with gold), learned from his teacher to express his best qualities as a whole in pictorial means. An example of his first well-known portrait is A. Navoi (XVI century). The poet of old age is depicted leaning on a cane. In exile, in the affairs of the emirate, in governing the state, his hair was gray and his will was polished.

He said, "Even though I am old, my body is alive, and my words are as sharp as a sword." Alisher Navoi portrays Mahmud Muzahhib in the miniature in the image of the great Alisher, his hair and beard are white, his body is slightly bent, his life is endless, his sharp eyes, a light smile on his lips, the poet is a nationalist, "humanist" and thinker. In terms of composition, this portrait has a unique feature in the art of miniature, its delicate image is expressed in the vitality, the movements of the eyes.

In the seventeenth century, the same Central Asian artists continued their traditions in miniature art far from their homeland. The artist Davlat Muhammad created portraits of the sultans and their families, court amirs, and poets at the Baburi Palace in India. During this period in India, Muhammad Murad Samarkandi worked at the Babur Palace and was named a master of portraiture. The miniature artist created a work based on the realities of the outside world observing and imagining life, following certain rules of composition. It should be noted that despite the rich cultural and aesthetic heritage of the peoples of Central Asia and Uzbekistan in the past, the art of realism has not found its form due to historical and objective conditions. In the 60s of the XIX century in Central Asia, Russian advanced realist art began to show its influence. Visiting artists depicted indigenous peoples and nature in their works.

V.Vereshagin, one of the first artists in Turkestan to create paintings of the "Turkistan Series", studied the ethnographic life as an observer of life and created works on various topics as a result of sketches. His "Trafficking in Minors," "Prison," and "Drug Addicts" are among them. His greatest work in the historical genre is called 'Celebrating.' The ceremony, which took place in Registan Square, reflected the victory over the forces marching against Independence.

In terms of composition, this multi-figure, multiplan play depicts the nature of Samarkand in a warm gamma in the light of the sun, which reflects the ordinary citizen, dervishes, soldiers on horseback, their psychological attitude to the 
CURRENT RESEARCH JOURNAL OF PHILOLOGICAL SCIENCES 2(5): 05-12,

May 2021 DOI: https://doi.org/10.37547/philological-crjps-02-05-03

ISSN 2767-3758

(C)2021 Master Journals

\section{Crossref do) 81 Google}

Accepted21 $1^{\text {th }}$ May, 2021 \& Published 26 $6^{\text {th }}$ May, 2021

ceremony, their national costumes.

Uzbekistan was founded on the basis of modern realistic fine arts by Russian artists who came to Uzbekistan in the early twentieth century. Among the first was Artists like M. Kurzin, P. Bure, I. Kazakov, A. Isupov, N. Rozanov. In 1918 in Samarkand, in 1919 in Tashkent Turkestan Regional Art Schools were established, among other artists A. Volkov taught the youth. In Samarkand, 0. Tatevosyan was in charge.

0. Tatevosyan was known as an artist in the 20s. He tried himself in the genres of landscape, still life, portrait, everyday life, and in his works he interpreted the East in his own way. He later became known as a professor of still life and taught young artists from 1954-57. In 1924, N. Rozanov was the first to establish a studio of fine arts at the Museum of Art. In this national studio, Uzbek artists X. Valiev, Z. Saidnosirova, A. Oshkentboev, O. Tansiqbaev and others were the first to learn. N. Rozanov as I. Kazakov also taught young people the basics of Russian realist art. Along with realistic art Petrov -Vodkin, Several artists, such as N. Kuznetsov and A. Volkov, turned to the formalist direction. One of the implementers of this direction is A. Volkov. His works such as "Pomegranate Teahouse", "Caravan", "Player in Sandalwood" were exhibited in 1924 at a solo exhibition in Tashkent, Moscow. After being criticized by the public, a realistic direction was decided. Volkov made a breakthrough in his work after The Pomegranate Tea House. In his memoirs, he emphasized that the path of realism is the right path in the creation of the human image. The way of realism was reflected in the works of selfportrait, portrait of his wife, kolkhoz worker, cotton picker, "Bayram".

\section{Conclusion}

In conclusion, we note that the history of the development of schools of fine art and composition in the Asian region and Uzbekistan dates back to ancient times. The objects of fine art found on the territory of modern Uzbekistan have played a huge role in the development of world civilization with their attractiveness, high artistic compositional decision.

\section{REFERENCES}

1. Байметов, Б. Б. (2016). История развития изобразительного искусства Узбекистана. Наука, образование и культура, (1 (4)).

2. Baymetov, B. B., \& Sharipjonov, M. S. O. (2020). Development Of Students' Descriptive Competencies In Pencil Drawing Practice. The American Journal of Social Science and Education Innovations, 2(08), 261-267.

3. Boltabayevich, B. B., \& Shodievna, B. 0. (2020). Individual Approach To The Formation of Artistic And Creative Talents Of Students In Art Schools. The American Journal of Social Science and Education Innovations, 2(08), 637-642.

4. Boltabayevich, B. B, \& Pardaboy, K. (2020). Scientific and theoretical aspects of the formation of compositional abilities of students in painting classes. European Journal of Research and Reflection in Educational Sciences Vol, 8(3).

5. Байметов Ботир Болтабаевич. Актуальные вопросы подготовки педагогических кадров республике Узбекистан. Международный научный журнал «ВЕСТНИК НАУКИ» 2020/10. 
CURRENT RESEARCH JOURNAL OF PHILOLOGICAL SCIENCES 2(5): 05-12,

May 2021 DOI: https://doi.org/10.37547/philological-crjps-02-05-03

ISSN 2767-3758

(C)2021 Master Journals

\section{Crossref do) 81 Google}

Accepted21 ${ }^{\text {th }}$ May, 2021 \& Published 26 ${ }^{\text {th }}$ May, 2021

Том 1.10 (31). Страницы 5-9.

6. Байметов Ботир Болтабоевич. Тасвирий санъатдан бўлажак рассомўқитувчиларни касбий тайёрлашда композиция фанининг назарияси ва методикаси. Science and education journal. 2020/4. Стр. 461-467

7. Байметов, Б. Б. (2020). Педагогика олий таълим муассасаларида талабаларга композиция фанини ўқитишнинг назарияси ва амалиёти. Science and Education, 1(7).

8. Байметов, Б. Б., Султанов, Х. Э., \& Муратов, Х. Х. (2019). Психологические основы активизации творческих способностей студентов в процессе практических занятий. Вестник науки, 1(7), 67-71.

9. Байметов, Б. Б., \& Талипов, Н. Х. (2016). Методическая последовательность ведения работы над живописным портретом в педагогическом ВУЗЕ. Научная дискуссия: вопросы педагогики и психологии, (4-1), 46-50.

10. Baymetov, B. В. (2020). Development of The Ability To See And Represent The Form Remotely In The Process of Teaching Students To Portray A Creature In Higher Pedagogical Education. The American Journal of Applied sciences, 2(10), 154-159.

11. Botir Boltabaevich Baymetov. Development Of The Ability To See And Represent The Form Remotely In The Process Of Teaching Students To Portray A Creature In Higher Pedagogical Education. 2020/10 Журнал. The USA Journals. Том 2. Страницы- 154-159

12. 20. Botir Boltabayevich Baymetov. Technologies Of Moving Images Of People From Different Views In Fine Arts
Lessons. The American Journal of Social Science and Education Innovations. The American Journal of Social Science and Education Innovations (ISSN - 2689100x) Published: January 31, 2021. Стр. 463-468

13. BB Baymetov. Inson qomatining turli ko'rinish va holatlaridan qisqa muddatli tasvirlaridan bajarish myetodikasi. "Science and Education" Scientific Journal January 2021 / Volume 2 Issue. 357-365

14. Botir Boltabaevich Baymetov. oliy pyedagogik ta'limda bo'lajak tasviriy san'at o'qituvchilarining ijodiy qobiliyatlarini shakllantirishning ba'zi masalalari. academic research in educational sciences volume 2 | issue 1 | 2021. 277-283 бетлар.

15. BB Baymetov, $\mathrm{XX}$ Muratov.Tasviriy san'atdan amaliy mashg'ulotlarida talabalarning tasvirlash mahoratlarini takomillashtirish texnologiyalari.Science and Education, 2021.349-354.

16. Мукаддам Тожикузи кизи

Хамрокулова, Рашид Неъматович Зульфиев, Ботир Болтабаевич Байметов. Теория и практика преподавания академического рисунка в подготовке будущего художника педагога. Science and education scientific journal. 2020/12.Tом 1. Номер 9. стр 364-372.

17. Botir Boltabaevich Baymetov. Art of Modern Uzbekistan: The History Of Its Development During The Years of Independence. The American Journal of Social Science and Education Innovations. 2020/10. 125-132.

18. BB Boltaboevich. Methods of portraiture in the process of making sketches and drawings of the human face in higher 
CURRENT RESEARCH JOURNAL OF PHILOLOGICAL SCIENCES 2(5): 05-12,

May 2021 DOI: https://doi.org/10.37547/philological-crjps-02-05-03

ISSN 2767-3758

(C)2021 Master Journals

\section{Crossref do) 81 Google}

Accepted21 ${ }^{\text {th }}$ May, 2021 \& Published $26^{\text {th }}$ May, 2021

pedagogical education. International Journal of Psychosocial Rehabilitation, 2020. Том 24. Номер 5.Страницы 64086415.

19. Botir Boltabayevich Baymetov. Technologies Of Moving Images Of People From Different Views In Fine Arts Lessons. The American Journal of Social Science and Education Innovations. 2021/1. The American Journal of Social Science and Education Innovations (ISSN - 2689-100x) Published: January 31, 2021.том 3.номер 1. Страницы 463468.

20. BB Baymetov.Inson qomatining turli ko'rinish va holatlaridan qisqa muddatli tasvirlaridan bajarish myetodikasi"Science and Education"Scientific. January 2021.Volume 2Issue1.357-365.

21. BB Baymetov, $X X$ Muratov. Tasviriy san'atdan amaliy mashg'ulotlarida talabalarning tasvirlash mahoratlarini takomillashtirish texnologiyalari. Science and Education, 2021. 349-356.

22. Botir Boltabaevich Baymetov Xusan Xolmuratovich Muratov. Methods Of Teaching Students To Do Sketches In Independent Learning.2020/12. The American Journal of Social Science and Education Innovations. 2. Номер 12. Страницы 8-13

23. Ulfat Shuxratovich Ismatov Botir Boltabaevich Baymetov. Pedagogika oliy ta'lim muassasalarida talabalarini bosh namunasini tasvirlashga o'rgatish orqali tyexnik mahoratlarini takomillashtirish. 2020/11. "Science and Education" Scientific Journal November 2020 / Volume 1 Issue 8 Страницы 476-484

24. Laylo Mirsoatova Botir Boltabayevich
Baymetov. Oliy pyedagogik ta'limda inson qomatini tasvirlashning nazariyasi va myetodikasi.2020/11 "Science and Education" Scientific Journal November 2020 / Volume 1 Issue 8. Страницы 467475

25. Botir Boltabaevich Baymetov, Ulfat Shuhratovich Ismatov. Development of competencies of future fine art teachers in description of nature in graphic materials. 2020. ACADEMICIA: An International Multidisciplinary Research Journal.том 10.Номер 11.Страницы 864-871.

26. Botir Boltabaevich Baymetov. Creativity Of The Outstanding Artist-Miniaturist Kamaleddin Behzad (1455-1536). INTERNATIONAL SCIENTIFIC AND CURRENT RESEARCH CONFERENCES "SCIENCE AND INNOVATION IN THE XXI CENTURY: CRUCIAL ISSUES, DISCOVERIES AND ACHIEVEMENTS" Doi - https://doi.org/10.37547/iscrc-intconf 03 2021/2/19.Pages: 67-71. Hungary, Europe.

27. Shoxidahon Odiljonovna Botirova Boltabaevich Baymetov. Theoretical foundations of coloring in the organization of fine arts classes.2021/4. ACADEMICIA: An International Multidisciplinary Research Journal https://saarj.com.Toм 11,номер 4,Страницы 775-782.

28. Bobur Abdugani Ogli Nabiyev Botir Boltabayevich Baimetov. Technologies for Improving the Composition of Students in the System of Higher Pedagogical Education 2021/4. The American Journal of Social Science and Education Innovations.Номер 03. Страницы 64-70 
CURRENT RESEARCH JOURNAL OF PHILOLOGICAL SCIENCES 2(5): 05-12,

May 2021 DOI: https://doi.org/10.37547/philological-crjps-02-05-03

ISSN 2767-3758

(C)2021 Master Journals

Crossref do) 80 Google

Accepted21 ${ }^{\text {th }}$ May, 2021 \& Published 26 $6^{\text {th }}$ May, 2021

29. Pardaboy Khudoyberdiev Baimetov Botir Boltabayevich Use The Theoretical Foundations Of Color Science In Teaching Students To Work With Educational Productions From Painting.2021/3. The American Journal of Social Science and Education Innovations. Hомер 03.Страницы 330-337.

30. Muxiddin Sharipjonov Botir Baymetov. Oliy pedagogik ta'limda talabalarga inson qiyofasini amaliy tasvirlash jarayonida ijodiy kompyetyensiyalarini rivojlantirish. 2021. ACADEMIC RESEARCH IN EDUCATIONAL SCIENCES. Том 2.Номер 3.1066-1070.

31. Iqboloy Ibrahimova Botir Boltabaevich Baymetov. Technologies for using fine arts in developing students' artistic imagination. 2021/4. Asian Journal of Multidimensional. Research (AJMR) https://www.tarj.in.Toм 10.4. 544-551. 